\title{
LEXICAL TRANSFER IN L2 ACQUISITION AND ITS COGNITIVE CATEGORIES (A CASE STUDY OF LITHUANIAN AS A FOREIGN LANGUAGE)
}

\author{
JÓZEF MARCINKIEWICZ
}

\section{Introduction}

In line with the assumptions of Ronald W. Langacker's Cognitive Grammar CG (cf. inter alia, Langacker, 2000, 2003; Dąbrowska and Kubiński, 2003), language transfer, as an occurrence of linguistic interference, can be defined as shifting standardized conventional linguistic units of the first language (L1) to the user's second language (L2). Within the L2 system, these units are not considered either standard or conventional and are thus regarded as errors. In other words, the analyst deals with the influence that a bilingual speaker's (learner's) knowledge of one language may have upon their understanding, processing, storing and production of words in another language. This process is obviously mental (taking place on the mental plane), and as such it should be analyzed in terms of mental operations, primarily comparison and categorization, which an L2 user performs in a specific bilingual speech event when they find themselves restricted by the asymmetry of L1/L2 linguistic resources. Competence differences between L1 and L2 in the process of L2 acquisition occur with no exception and concern the standard of comparison (dominant L1) and the target object (dominated L2), which is usually found incomplete within some of its linguistic categories, especially the mental lexicon (cf. Marcinkiewicz, 2013: 71-2).

Under John R. Taylor's (2001: 79-81) views on linguistic categorization, it is lexis that should be assigned the status of the basic level category. In terms of cogni- 
tive and linguistic factors, lexis is the most distinctive and arguably the most important category of all language levels. Within the phenomenon of linguistic interference, from the communicative perspective, lexical-semantic transfer is the most important and noticeable error type. Therefore, it is not surprising that it has always been the most evident kind of language transfer and thus most frequently analyzed by linguists interested in the process of L2 interference (e.g. Piotrowska-Oberda, 2006; Lauterbach, 2009; Podgórni, 2010; Marcinkiewicz, 2014; 2016).

This type of transfer, i.e. the cognitive categories of lexical transfer, will remain the focus of our attention in the present paper. In what follows we shall try to present some of the numerous examples of lexical-semantic acquisition errors collected from Polish speaking students of Lithuanian during their practical language class, which is part of the Lithuanian Studies program at Adam Mickiewicz University in Poznań.

The semantic analysis will be based on Cognitive Linguistics theoretical models, such as R.W. Langacker's (1987; 1990; 2000) Cognitive Grammar framework, Eleonor Rosch's (1978) prototype theory, J.R. Taylor's (1989) linguistic categorization, George Lakoff and Mark Johnson's (1980) Conceptual Metaphor Theory as well as G. Lakoff's (1987) Idealized Cognitive Models (ICM) and semantics of perception, and Gilles Fauconnier's (1985) and G. Fauconnier and Mark Turner's (2002) linguistic concepts.

\section{The cognitive model of lexeme transfer}

Within the process of generating errors of primary significance is the mechanism of linguistic transfer, which should be understood as the proper mental process at the level of our thinking. This process forms an element of the language user's cognitive predispositions connected with the abilities to compare and to transform; it is thus responsible for the ability, for instance, to complement an L2 learner's incomplete store of phonological, morphological, semantic and symbolic structures (in other words, the store of structures determining a speaker's linguistic competence) of the second language (L2). The mechanism involves language processing and has to make frequent use of the set of categories entrenched in the process of first language (L1) acquisition (cf. Marcinkiewicz, 2011: 140-1; 2013: 72).

As I have argued elsewhere (Marcinkiewicz, 2016), we can posit that lexical transfer originates in our mind as it stores archetypes which become activated in the form of specific language transfer. The key role in triggering this transfer as part of a speech event seems to be played by what could be termed communicative obligation in a bilingual setting. It is this communicative need at a particular time and in specific conditions that initiates in the user's brain, when the data begins to be pro- 
cessed, the semantic context of a projected message, which is either required or expected. In order to re-express the message in L2, the next stage of data processing in the brain consists in associating the data and initiating a mental signal that a particular unit is missing in the user's L2 mental lexicon. This phenomenon can be termed the ascertainment of a semantic gap, which for the transfer may constitute the most important signal as the neural processing begins. According to Langacker's concept ${ }^{1}$, the main stimulus, or attractor activating a 'rescue' model from the L1 lexicon seems to be the meaning context of the semantic gap, which results from the projected sense of an expression in L2 usage. Following another stage of mental processing, which is based primarily on categorization, a suitable L1 unit is activated and instantiated in an L2 message. This operation of gap 'filling' can be interpreted as a situation saving device that ensures the message's semantic continuity in a specific communicative setting.

The schematic process of categorization in lexical transfer is visualized in Fig. 1.

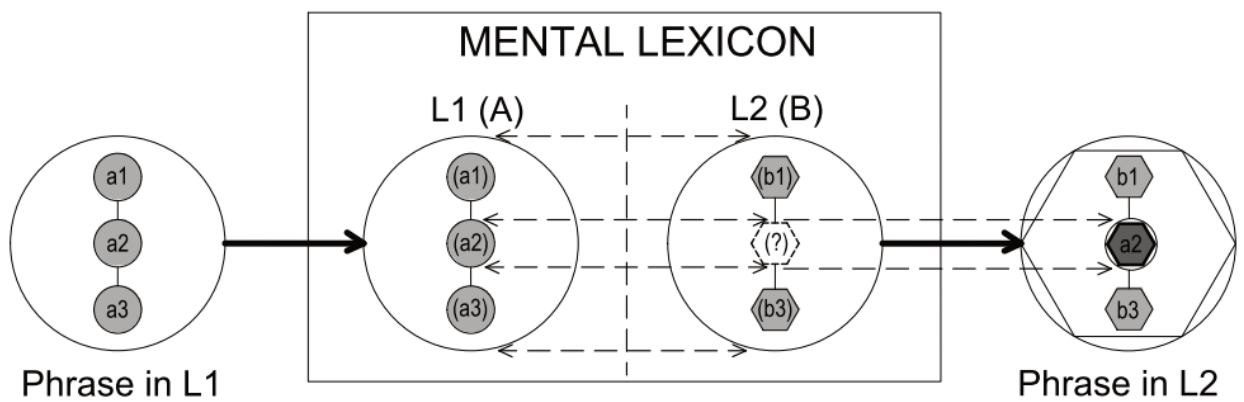

Figure 1. The cognitive model of lexeme transfer

The above scheme is a simplified illustration of categorization, which, according to Langacker, consists in "the full activation of pattern [A]", i.e., an L1 unit marked (a2), "to categorize (B)", i.e. an L2 unit (b2), which in schema marked as (?). The unit then becomes instantiated, i.e., produced in the context of a phrase in L2

\footnotetext{
${ }^{1}$ The following is what Langacker (2000: 7-8) has to say about categorization in the context of the brain's processing operations: "Categorization is then interpretable as capture by an attractor. Presenting the system with a certain input tends to activate a variety of previously established patterns, some of which may be mutually inhibitory. When an input (B) results in the full activation of pattern [A] - which may have won out over numerous competitors - we can reasonably say that $[\mathrm{A}]$ is used to categorize (B). Of course, if the input is only fragmentary, categorization via the activation of [A] may serve to reconstitute the full, familiar experience it represents. The categorizing experience will also be qualitatively different depending on whether (B) is compatible with $[\mathrm{A}]$ or succeeds in eliciting $[\mathrm{A}]$ despite some discrepancy between them".
} 
(the relationship is marked by the thick arrow). The activated unit (a2), linked with the semantic context, represents "the full, familiar experience" in L1 - a lexicalsemantic unit which comes from the user's linguistic and cognitive competence. Moreover, the activated model (a2) in the L2 phrase can be described as "qualitatively different" for two reasons. Firstly, it is related to experience from outside the target language. Secondly, it categorizes the missing concept $\langle\mathrm{b} 2\rangle$, which in principle is an element of another "linguistic world" (Bartmiński, 1990), or the transferred category as a blend, in Fauconnier's (1985) terms, understood as a result of a clash of two language systems in a bilingual usage setting ${ }^{2}$ (cf. Marcinkiewicz, 2016: 300-2).

\section{Lexical transfer vs. cognitive categories: a short case study}

I propose a lexical transfer case study at the semantic level, analyzing it in terms of bilingual processing, which is reflected by some types, such as: (i) 'misses', concerning the central prototypical element of the lexeme meaning (errors of missing the sense of metaphorical extension), (ii) missing the sense of synonymous words in hierarchical classes of quasi-synonyms, (iii) missing the sense of homophones, which is called a "false friend" transfer, and (iv) direct transfer. Furthermore, errors are analyzed in relation to polysemy - in radial categories or chaining schemes, or from the perspective of other frameworks and tools, such as: CG, ICM-s or conceptualization in general. $^{3}$

\subsection{Missing the sense of the metaphorical-metonymic extension in radial categories}

Lexical transfer most often refers to the central element of the prototypical meaning (in prototype-based categorizations). Lexical errors of this type can be defined "misses" in the choice of the proper meaning of a lexeme, i.e. "faulty word choices" as a result of the "false alarm" phenomenon. ${ }^{4}$ Naturally, this is associated

\footnotetext{
${ }^{2}$ On the theory of blending, see Fauconnier and Turner, 2002, and Libura, 2010.

${ }^{3}$ On prototypes, polysemy, and radial categories see Taylor, 1989, 2001; on polysemy under the cognitive approach see Krzeszowski, 2012: 109-11); on Idealized Cognitive Models (ICM) and radial categories see Lakoff, 1987, 2011; on construal see Langacker, 1990, 2008, 2009, 2013; on Vantage Theory see MacLaury, 1995; Głaz, 2009.

${ }^{4}$ Inappropriate loanwords, or faulty word choices, interpreted in the context of the general psychological processes, can be compared to the psychological 'false alarms' phenomenon, understood as the
} 
with a limited ability to complement an L2 learner's incomplete store of semantic and symbolic structures (incomplete mental lexicon). Finally, according to Lakoff (1987: 129-30), the semantics of perception entails categorization, and this does not have to be completely congruent with reality because it is dependent on acquired ICM-s, i.e. cultural experiences such as knowledge, stereotypes, etc. Naturally, what also needs to be taken into account is linguistic knowledge. In the examples below, broader context will be provided to show the right sense of this kind of error.

Example: the radial category ŻYCIE [LIFE]; transfer: Pol. życie > Lith. gyvybe :

(1) Pol. jakość życia ludzi > Translated into Lith. as: žmonių gyvybès kokybè (pr3) ${ }^{5}$, (Eng.: 'quality of human life [in a biological sense]');

Model translation: 'žmonių gyvenimo kokybė', (Eng.: 'quality/standard of human life').

(2) Pol. zwolennik amerykańskiego stylu życia > Translated into Lith. as: amerikonu gyvybès buities šalininkas ${ }^{6}$ (mm5), (Eng.: 'advocate of Americans life (and mode of life)');

Model translation: 'amerikietiškos gyvensenos šalininkas', (Eng.: 'follower of the American lifestyle/ way of life').

(3) Lith. jis pataikè ne kartą sukomplikuoti savo gyvybę (mm4), (Eng.: 'He could often complicate his life [in a biological sense]'): < generated from Polish: *on potrafił nie raz skomplikować swoje/sobie życie;

Model translation: 'jis buvo linkęs/mokèjo komplikuoti savo gyvenimą', (Eng.: 'He was inclined to complicate his life' .

Examples (1), (2), and (3) include erroneous translations of the Polish polysemic noun życie. The Lithuanian equivalent gyvybe ('life' in biological sense), used as gyvybés (gen.sg.) and gyvybe (acc.sg.) in inflected forms, is inappropriate here and it replaces the correct form gyvenimo or gyvenima ('life' in the social sense) or gyvensena (lifestyle). In the Polish language (L1), like in English, the same noun zycie (life) means both 'life in the biological sense' = Lith. gyvybe, and also 'life in the social sense' = Lith. gyvenimas. The semantic differences in both languages can be illustrated through a visual representation of the idealized cognitive models of the radial category Pol. ŻYCIE, and the chain-related Lithuanian categories GYVYBÉ, and GYVENIMAS:

result of information processing at the stage of perceptual categorization, i.e. false recognition of schemata, see papers in cognitive psychology, e.g. Falkowski etc., 2008: 371-2; Wojciszke etc., 2010: 301.

${ }^{5}$ (pr3) - The identifier of the student and the Lithuanian course level.

${ }^{6}$ In these examples I analyze the errors that are the subject of the article only, while the other errors are corrected in the model translation. 


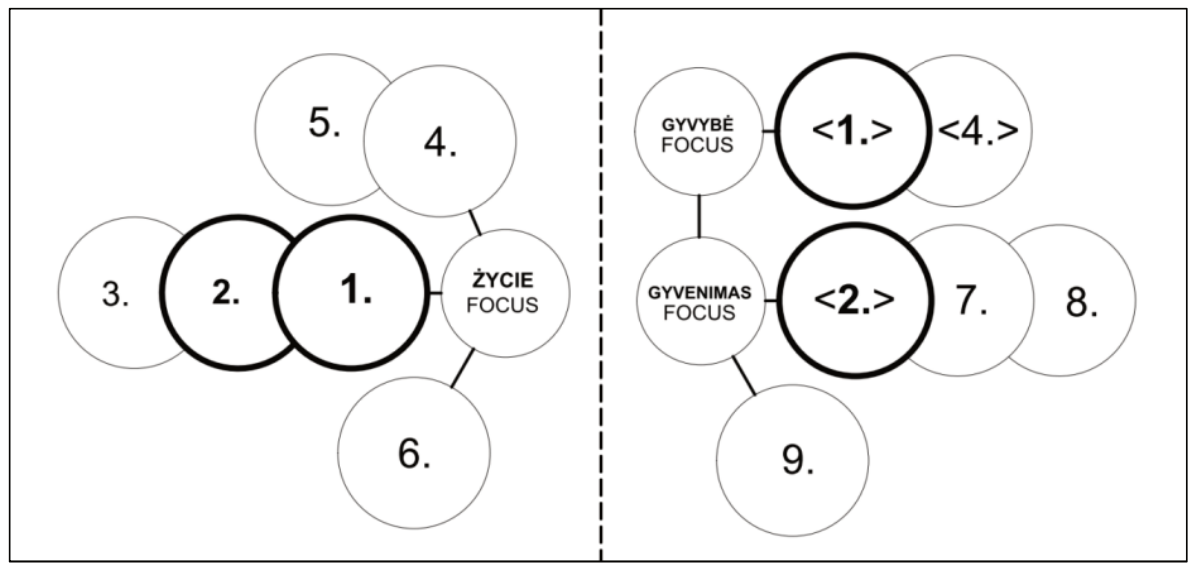

Figure 2. Model of the radial category Pol. ŻYCIE vs. chain related categories Lith. GYVYBĖ and GYVENIMAS

As can be seen, the ŻYCIE model includes six basic meanings (taken from the Polish SJP dictionary) divided into three semantic feature bundles, and two of them with metaphorical-metonymic extensions of meaning: (i) 1. life in the biological sense, extended into meanings 2. life in the social sense, and 3. sustenance; (ii) 4. energy, vitality, extended into meaning 5. lively energetic mood; and (iii) 6. functioning of something.

In the Lithuanian DLKZ dictionary there are two lexemes: (i) gyvybe carries the essential meaning $<1 .>$ condition that distinguishes animals and plants from the earth (synonymous with the Polish meaning 1.), and the metaphorical extension $<4$.> live force (close to the Polish meaning 4.). The other one (ii) gyvenimas primarily means: $<2$.> existence, inhabitation (same as the Polish 2.), extended into meanings 7. the period between birth and death, and 8. good life, prosperity, and in a discrete metonymic sense 9 . residence or residency.

As shown above, these two relations of polysemy are different. The main two meanings of the Polish zycie (1. and 2.), which are related in the chaining schema, in Lithuanian are expressed by separate words, not being parts of the same category, as in Polish, but they constitute two chain-related units. The semantic analysis shows that the choice of the incorrect equivalents is determined by two factors: (i) certain meaning categories of the source language lexeme (correlated in polysemy), and (ii) the need to choose one of two possible forms in the target language.

At the mental level, the key role in bilingual processing is played by the meaning activation with a certain input, i.e. the form and conceptualization of a lexicalsemantic unit in the source language. ${ }^{7}$ It can be assumed that a linguistic expression,

\footnotetext{
${ }^{7}$ It features the so-called reference point, see Langacker, 2008: 83-5.
} 
understood as a reference point in directing our attention, instantiates the path of mental access to the L2 relevant resources (cf. Langacker, 2008: 81, 333, 501-505). In our case the path of access is apparently more complicated due to a different conceptualization of equivalents. Instead of one polysemic lexeme $\dot{z} y c i e$, there are two units to choose from: gyvybe and gyvenimas, which are members of two different radial categories.

Under the cognitive grammar approach, in the search (categorization) for an equivalent L2 lexeme, what is important is similarity to the source language lexeme in terms of compositional path. ${ }^{8}$ In Polish, the lexeme zycie (1 and 2), which is inflectionally derived from the verb $\dot{z} y c$ ' 'live' has a maximally simplified compositional path: $\dot{z} y c+(i) e$. The Lithuanian equivalents, as the suffixal derivatives (with $-y b \dot{e}$ and -imas) are more complex. Gyvybe is derived from the adjective gyvas 'alive' while gyvenimas from the verb gyventi 'to live/to exist', and is compositionally more complex $(g y v+e n+i m a s)$. It seems that the choice of the morphologically simpler equivalent gyvybe could have been motivated by the greater compositional similarity coupled with the formal inflectional analogy (the $-e$ ending).

\subsection{Missing the sense of synonymous words in hierarchical classes of quasi-synonyms}

Analysis of lexical transfer in the acquisition of Lithuanian shows that the error generation process is often triggered by synonymy, especially within hierarchical structures, the so-called quasi-synonyms. ${ }^{9}$ Every language features a number of concepts, which besides being polysemic by nature, occur in a synonymic relationship with other concepts, with which they share a common semantic field. Below are a few examples of quasi-synonymic source language (Polish) concepts, which, if used in the target language (Lithuanian), result in 'misses'. In all of these cases, synonymy was the main cause of errors. The errors were generated not only as a result of mixing the granularity of concepts (the degree of specificity) of the equivalents used but also due to the different conceptualizations of the semantic scopes of concepts or pragmatics indicating the specificity of particular lexemes.

\footnotetext{
${ }^{8}$ Langacker (2008: 61) says that “an expression's meaning does not consist of its composite semantic structure alone, but further includes its compositional path, the two standing in a foreground/background relationship. While the composite conception is primary, it is viewed against the background of the component semantic structures at all lower levels".

${ }^{9}$ On the chains of quasi-synonyms and the overlap of their semantic fields, see Apresjan (1980: 318-20). With regard to imagery, the relation of specificity and the hierarchy of conventionally arranged conceptual types, i.e. the hierarchies consisting of successive whole-part relations are discussed by Langacker (2008: 56, 64). The concept of the taxonomic network is used in the same sense by Taylor (2001: 36-7).
} 
Example: the synonymous categories: DZIAŁANIE, CZYNNOŚĆ, ZAJĘCIE, (general terms of ACTIVITY); transfers: Pol. działanie > Lith. veikla; Pol. czynność $>$ Lith. veikla; Pol. zajęcie > Lith. veiksmas:

(4) Pol. jakie działanie [ma na ludzi] > Translated into Lith. as: kokị veikla [-] (bk4), (Eng.: 'what activities [-]');

Model translation: 'kokị poveiki [žmonėms daro]', (Eng.: 'what impact/ effect [it has on people]').

(5) Pol. jaką czynność wykonuje to urządzenie > Translated into Lith. as: kokią veikla daro šis ịrenginys (zp5), (Eng.: 'what activities makes the device');

Model translation: 'kokị veiksma atlieka šis įrenginys', (Eng.: 'what (action /operation) this device performs');

(6) Pol. w rodzinach ulubionymi są inne zajęcia niż sport > Translated into Lith. as:

a. šeimose mėgama kitus veiksmus nei sportas (dpm4), (Eng.: 'in the families there are other favorite actions than sports');

b. šeimos mègstami kiti veiksmai nei sportas (jc3), (Eng.: 'in the family there are other favorite actions than sports');

Model translation: 'šeimose mėgstama/i kitokia veikla/ kitokie ǔ̌siemimai nei sportas', (Eng.: 'Families have other favorite activities than sports').

Considering the context of use of particular concepts, quasi-synonyms denoting general concepts of human activity can be arranged in a mutual relationship of specificity in the following way: działanie: czynność: zajęcie. Their Lithuanian equivalents would respectively be: poveikis: veiksmas: veikla (užsiemimai), while the English ones: impact (effect): action (operation): activity (work).

What follows is a coarse-grained overview of the respective examples without a detailed semantic analysis of the expressions. In sentences (4) and (5), the concept of veikla (activities) is used. The word comes from the third taxonomic level with the meaning of 'human activity', the narrowest of the whole range of concepts. However, the semantic context in both cases calls for equivalents with another level of 'granularity': in sentence (4) this would be poveikis (impact/ effect), the most abstract concept, which means 'activity', but in the general sense of 'impact'; in sentence (5), veiksmas (operation), the term from the middle level of the hierarchy with a more schematic meaning than the human 'activity'.

Example (6) illustrates the use of the term veiksmas (action). In the required semantic context of 'human activities', the concept of veikla/ užsiemimai (activities) tends to be favored in real usage rather than the more general expression that was actually used by the student. In this case, of key importance is the pragmatic factor, which reflects the specialization and semantic distribution of the two concepts under 
discussion: veiksmas is used in the general sense of human and non-human 'activity' while veikla in the specific sense of human 'action' or 'activity'.

In this particular case, yet another factor plays a key role: the strongly polysemic nature of the radial category of the Polish lexeme DZIAŁANIE, 'activity (in a broad sense)', which embraces the meanings of all expressions used in sentences (4-6). ${ }^{10}$ In bilingual processing, activating a specific equivalent from among a number of L2 items, through the polysemic path of mental access, which is instantiated with a certain input by the L1 radial category (with multiple meanings, such as the Pol. DZIAŁANIE) requires far more complex categorization than in the case of a 1:1 relationship of lexical-semantic units. The right selection can only be made by the user who has fully mastered the L2 relevant lexemes and their subtle meanings. In sum, the process of categorization entails confrontation of various models of radial categories or ICMs, just like in the case of the lexeme ŻYCIE, which was analyzed in the previous section (see Figure 2).

What also hampers the activation of a suitable equivalent is the phonetic (formal) similarity of the Lithuanian equivalents. In examples (4-6), the Lithuanian words are derivatives of the verb veikti, Eng. 'act', and share the same root -veik-. It is the morphological component of the compositional path that distinguishes them semantically. To a student of Lithuanian as a Foreign Language, the affixal derivatives of the same root, which differ only in morphemes, i.e. the prefix po- or the suffixes -smas and -la, can have very small, if any, semantic difference. According to Langacker (2008: 61-2), the abstract components of complex expressions establish a shortened compositional path, reducing thus the cognitive salience of the semantic background of the derived concepts. In this particular case, the only salient syntactic structure for the L2 user is the root-veik-, derived from the verb veikti, which in a cognitive sense is a shared semantic component of the expressions, and not a distinctive feature of the unit's meaning in a specific semantic context.

\subsection{Missing the sense of homophones: the "false friend" transfer}

The "false friend" transfer, a concept invoked in translation theory (see Odlin, 1989: 78-9; Wilczyńska, 1992; Kroschewski, 2000; Lipczuk etc., 2003; Szpila, 2003; Hejwowski, 2004: 204-5) is based on the association of identical or similar word forms (homophones) in bilingual language use and the assumption that they have identical meaning. This kind of transfer is more likely to occur if it involves internationalisms, i.e. words shared by multiple languages (cf. Maćkiewicz, 1992;

\footnotetext{
${ }^{10}$ Dictionary of the Polish Language SJP (www.sjp.pwn.pl) provides over 20 meanings, whereas dictionary of the Polish synonyms Synonimy.pl (www.synonimy.pl), supplies 26 synonyms.
} 
Lipczuk, 1992). The process itself is based on the fundamental psychological mechanism of association, and is linked with the ability to compare, categorize and activate in the user's mental lexicon an established symbolic relationship between a word form and its semantic pole (cf. Langacker, 2003: 35-6, 40-1).

The false friend transfer can occur in both directions of the bilingual relationship, depending on the direction of bilingual processing: either as L1-L2 transfer or as feedback transfer from L2 to L1. However, it should be borne in mind that despite the change in the direction of processing, the transfer of the wrong meaning to the target language is always based on the activation of the lexical-semantic unit's content, which has been conventionalized in the user's L1 language (Marcinkiewicz, 2014: 187).

The "false friend" transfer is possible if the homophones in the contact languages have different meanings or if their semantic fields overlap only partially, which is exemplified by the following examples.

Examples with Pol. PRODUCENT, KONSUMENT, ORDER, PREZYDENT and IMPORTER;

(7) Pol. producentom i importerom > Transferred into Lith. as: producentams ir importuotojams (rm3)/ producentams ir *importerams (zp3), (Eng.: 'for producers and importers');

Model translation: 'gamintojams ir importuotojams/ importininkams', (Eng.: 'for manufacturers and importers');

(8) Pol. producenci (filmowi) > Transferred into Lith. as: producentai (mm4), (Eng.: 'producers [in nature]');

Model translation: '(filmų) prodiuseriai', (Eng.: '(film) producers');

(9) Pol. czy na wyborze konsumenta zaważa tylko korzyść > Transferred into Lith. as: ar konsumento pasirinkimą lemia tik nauda (zp5, rm5), (Eng.: 'is the consumer's [in nature] choice influenced only by benefit?');

Model translation: 'ar vartotojo pasirinkimą lemia vien nauda', (Eng.: 'is the consumer's [user's] choice influenced only by benefit?');

(10) Pol. order [as a distinction] > Transferred into Lith. as: orderis (xx5), (Eng.:'order [as a command]');

Model translation: 'ordinas', (Eng.: 'order [as a distinction]');

(11) Pol. prezydent Monachium > Transferred into Lith. as: Miuncheno prezidentas (bk4, rk4, mm4, zp4), (Eng.:'President of Munich');

Model translation: 'Miuncheno meras', (Eng.: 'Mayor of Munich'). 
In examples (7-9), the Polish nouns producent (producer) and konsument (consumer) are the radial categories which contain meanings from the domains of HUMAN ACTIVITY (nomen agentis) and NATURE (expert terms). The Lithuanian homophones (with their inflected forms) exist as specialist terms in the domain of NATURE. The word producentas (producer) can be used in the sense of 'manufacturer'; however, from the point of view of pragmatics, it occupies a marginal position as the most commonly used word in this meaning is gamintojas (producer). In example (8), the Polish concept of producent filmowy (film producer) is rendered in Lithuanian through direct transfer from English as prodiuseris < Eng. 'producer', which in this case also does not match the Polish model of the radial category PRODUCENT (producer).

The Polish lexeme konsument (consumer) occurs in the identical relationship. In Lithuanian, the homophone konsumentas (consumer) is employed only as a term in the domain of NATURE, while in the 'commercial' meaning, the word vartotojas is always used.

The Polish order, Eng. 'order', does not carry the same meaning as the Lithuanian orderis (order [as a command]). As can be seen in example (10), the Lithuanian meaning is close to the English 'order' whereas the correct equivalent of the Polish order is ordinas (order [as a distinction]).

Similarly, in example (11), the Polish lexeme prezydent (president) shares with its Lithuanian equivalent prezidentas only a part of the semantic field, primarily in the sense of the head of state. The distribution of meanings of these polysemic words in the models of the radial categories of PREZYDENT and PREZIDENTAS is an interesting example of how particular conceptualizations in both languages can converge and diverge. More specifically, the Polish prezydent denotes the mayor of a larger town or city (Lith. meras) while the Lithuanian prezidentas is employed in similar senses to the English 'president', and can refer to the chair of the supervisory board, CEO, or company head.

Finally, one comment requires the direct transfer of Pol. importer $>$ Lith. *importeris (importer) which is in the phrase (7). The transferred word in such a form in the Lithuanian language does not exist. By Lithuanian pragmatics are two possible equivalents in use: importuotojas or importininkas. The first lexeme is derived from the loan verb importuoti (to import) with the Lithuanian suffix tojas, and the second one from the loan noun importas (import) with the suffix -ininkas.

The 'false friend' transfer from Polish to Lithuanian can be illustrated with a wide range of examples of Latin-derived homophones that were mainly borrowed from English. Their semantics evolved in time in different directions through various trajectories. 


\subsection{Direct transfers}

Direct transfers occur when L2 users apply in L2 L1 lexemes whose forms are either not changed at all or such change is minimal. The category of noun is most frequent among direct transfers - which in Lithuanian receives the nominative case inflectional ending (for most paradigms). Direct transfers are frequently used when L2 learners need to fill in their lexical gaps, and, interestingly, they almost without any exception involve international lexemes (etymologically based primarily on Greek, and Latin stems).

Examples with Pol. PROKURATOR, NAUKI HUMANISTYCZNE, AGENCJA TURYSTYCZNA, RANKING, REPREZENTACJA:

(12) Pol. prokurator > Lith. *prokuratorius (jw4);

Model translation: 'prokuroras', (Eng.: '(public) prosecutor /attorney'.

(13) Pol. nauki humanistyczne > Lith. humanistinius mokslus (mb5);

Model translation: 'humanitarinius mokslus', acc.pl., (Eng.: 'Humanities (arts))'

(14) Pol. agencji turystycznej > Lith. turizmo *agencijos (mg5);

Model translation: 'turizmo agentūros', gen.sg., (Eng.: 'tourist agency').

(15) Pol. ranking (informally: raking) > Lith. *rankingas (zf5); *rakingas (xx5);

Model translation: 'reitingas', (Eng.: 'rating').

(16) Pol. reprezentacja w pitce nożnej > Lith. futbolo reprezentacija (kb4; jw4);

Model translation: 'futbolo rinktinè', (Eng.: 'football national team').

Examples (12-16) include direct transfers of the Polish nouns which are essentially international words. The proper Lithuanian equivalents, related to these transfers, are mostly the same loans (12-15), but they often come from different languages, and are characterized by different morphemes. The Lithuanian prokuroras (12) has a different suffix than the Polish prokurator, since it comes from the French procureur - the other name of 'prosecutor' (next to the Fr. procurateur). Of course, the borrowed word made its way to Lithuanian via the Russian прокурор.

Example (13) illustrates an error resulting from the different pragmatic features of the same internationalisms in Polish and Lithuanian. Both languages have adopted the same pairs of synonyms: practically homophonous adjectives with different suffixes: Pol. humanistyczny: humanitarny and Lith. humanistinis: humanitarinis. However, the problem is that despite the same etymology (English or French), the formally similar lexemes have gained different conceptualizations in their respective 
languages, with their meanings evolving somehow in opposite ways. As a result, the semantic equivalents are lexemes with different suffixes, i.e. the Polish humanistyczny (Eng. 'humanistic', Fr. 'humaniste') corresponds to the Lithuanian humanitarinis (Eng. 'humanitarian', Fr. 'humanitaire'). And conversely, the Polish humanitarny approximately corresponds to the Lithuanian humanistinis. More specifically, the Polish adjective humanitarny has a specialized shade of meaning and is used in the sense of 'the human approach' rather than in the sense of 'the study of the human being', which is included in the meaning of the adjective humanistyczny. By contrast, in Lithuanian the term for 'the study of the human being' is humanitariniai mokslai (mostly in the plural) while the relational opposite humanistinis has a more general meaning which is associated with 'humanism' (on relational opposites or converses, see Apresjan 1980: 353). In conclusion, it can be added that in both languages these lexemes belong to the similar hierarchical conceptual structures (quasisynonyms). However, the key difference is that the morphological analogues have been assigned opposite meanings.

Example (14) is in many ways analogous to (12). The Polish agencja and the Lithuanian agentüra (Eng. 'agency', Fr. 'agence', Ger. 'Agentur') have apparently been borrowed from different languages. Judging by the above equivalents, the Polish word seems to be formally closer to the English or French analogues while the Lithuanian word is derived from German. The probable reason for the mental activation of the 'missed' and practically unused Lithuanian equivalent *agencija (with the -ija suffix) is the varied semantic-formal structure of the radial categories of the lexemes in question. The Lithuanian radial category of AGENTŪRA corresponds to two units in Polish: AGENCJA and AGENTURA. As stated above, every case of asymmetrical equivalence is likely to hamper the user's search for a suitable equivalent. Moreover, in this particular example, the lexical-semantic unit Pol. agentura carries negative connotations, evoking the image of 'foreign, illegally operating intelligence services'. In my view, this pejorative semantic association can be an obstacle on the path of mental access to the activation of the homophonous equivalent.

The direct transfer of the Polish ranking/ raking > Lith. *rankingas/*rakingas, instead of the correct Lithuanian Equivalent reitingas (15) is yet another example of filling in a semantic-lexical gap with an international word. In the competition of language planes, the L1-transferred unit wins over the right Lithuanian equivalent, which even though it has been borrowed from English, just like ranking in Polish, it is derived from one of the quasi-synonyms: Lith. reitingas < Eng. 'rating'. Based on the many analysis of lexical transfer, it can be concluded that bilingual users find it easiest to transfer to L2 lexical resources from the common stock of internationalisms (see the section 3.3. on 'false friends'). The increased activation of international vocabulary in L2 should be linked with its productivity and mental access, which is based on the strengthened 'signal' or information in the mental dictionary of numerous languages. 
The last example of direct transfer (16) is in some ways different from the previous ones. Two types of transfer are invoked here: direct transfer of the Polish lexeme reprezentacja > Lith. reprezentacija (Eng., literally, 'representation') and conceptual transfer of the complex expression reprezentacja $w$ pitce nożnej > Lith. futbolo reprezentacija (English, literally, 'representation in football'). In this context, the following comments can be made: (i) in Lithuanian, the loanword reprezentacija is a hardly ever used word with the general connotation of 'representing' and does not occur in any specialist dictionary of sports language; (ii) the whole compositional path of the L1 expression is transferred to L2; the transfer includes all of the semantic components, i.e. the Polish reprezentacja and pitka nożna (on the language of football, see Lewandowski, 2013); (iii) the concept of 'football team' integrated in this manner sounds alien in Lithuanian, at least from the pragmatic perspective; (iv) in opposition to this, the main component of the Lithuanian specialist term futbolo rinktine is the noun rinktine, which carries the specialist meaning of 'national team'. Its propositional ICM includes the prototypical meaning of the Lithuanian verb rinkti = Eng. 'select'; (v) the Lithuanian attributive futbolo (gen.sg.) is by nature different from the Polish equivalent: first, it is the transference of the English 'football', secondly, its conceptual integration contributes a subtly different meaning of the genitive premodifier. In view of the above statements, the two concepts are explicitly different, especially at the level of their conceptualization.

\section{Conclusions}

1. When we view L2 language acquisition from the standpoint of R.W. Langacker's Cognitive Grammar and take into account the cognitive mechanisms that underlie the approach, we are able to redefine linguistic transfer as a cognitive phenomenon. For it is obvious that both the circumstances and the necessary conditions in which language errors are generated belong to the world of thought: $a$. linguistic transfer takes place at the mental plane of a speaker who is capable of using (at least) two languages; $b$. the process concerns specific transfers of language categories from L1 to L2 (sometimes conversely) in the course of a specific act of bilingual language use; $c$. from the psychological point of view we seem to observe an act of complementing the insufficient L2 language store with faulty "substitute replacements" coming from the native L1 store and such an act must be viewed as the bilingual speaker's reaction to the communicative compulsion (i.e. they must talk at school or have to understand and be understood in real life communicative situations); $d$. the mechanism of language transfer concerns the processing and transforming of the stored linguistic knowledge - i.e., mental operations of comparing and categorizing performed by the L2 user given the asymmetry of the two language stores (dominating primary L1 and secondary-target L2); $e$. the store of words in the 
L2 user's mind - their mental lexicon - most frequently includes prototypical categories structured in terms of prototype nuclei or schemata.

2. Analyzing errors generated at the level of all linguistic structures we noted that the category WORD should be regarded the central and most important category that is transferred from one language to another. The transfer of WORD always implies that something happens at two mutually interdependent and equally important (basic) levels: the semantic plane and the grammatical plane, at which the transfer to L2 of first language (L1) categories takes place.

3. The errors of the lexical-semantic plane (subject of analysis of this paper) most frequently involve: (i) the so called 'false alarms' or misses when the L2 user misses the central element of the prototypical meaning (its 'primary sense'), (ii) missing the sense of synonymous words in hierarchical classes of quasisynonyms, (iii) missing the sense of homophones, which is called a "false friend" transfer, (iv) direct transfer (at the level of the so called international words), and generally, (v) polysemy (radial categories, family resemblance and semantic chains) and synonymy.

4. Equally important types of errors such as: (vi) proper conceptualizations within special domains (making use of the L2 user's encyclopedic knowledge) or (vii) a clash between common and expert categories, which is not included in this paper it remains the subject of a further research.

Translated by Marcin Lewandowski

\section{References}

Apresjan, J. 1980. Semantyka leksykalna. Synonimiczne środki języka. Przeł. Z. Kozłowska i A. Markowski. Wrocław: Ossolineum.

Bartmiński, J. 1990. Językowy obraz świata. Lublin: UMCS.

Dąbrowska, E. and W. Kubiński. 2003. „Akwizycja języka w świetle językoznawstwa kognitywnego”. In: Dąbrowska, E. and W. Kubiński. (eds.). Akwizycja języka w świetle językoznawstwa kognitywnego. Kraków: Universitas. 9-29.

DLKZ - Dabartinés lietuviu kalbos žodynas [Dictionary of Current Lithuanian, 4th Edition]. 2000. Vilnius: Mokslo ir enciklopedijų leidykla.

Falkowski, A., Maruszewski, T. and E. Nęcka. 2008. „Procesy poznawcze”. In: Strelau, J. and D. Doliński (eds.). Psychologia. Podręcznik akademicki. Vol. 1. Gdańsk: Gdańskie Wydawnictwo Psychologiczne. 339-510.

Fauconnier, G. 1985. Mental spaces: aspects of meaning construction in natural language. Cambridge, Mass.: MIT Press.

Fauconnier, G. and M. Turner. 2002. The way we think: conceptual blending and the mind's hidden complexities. New York: Basic Books.

Głaz, A. 2009. "Cognition, categorization, and language: cognitive grammar meets Vantage Theory". Rice Working Papers in Linguistics 1. 242-59.

Hejwowski, K. 2004. Translation: a cognitive-communicative approach. Olecko: Wydawnictwo Wszechnicy Mazurskiej Acta Universitatis Masuriensis. 
Kroschewski, A. 2000. False friends und true friends. Ein Beitrag zur Klassifizierung des Phänomens der intersprachlich-heterogenen Referenz und zu den fremdsprachendidaktischen Implikationen. Frankfurt am Main: Peter Lang.

Krzeszowski, T.P. 2012. Meaning and translation. Part 1: Meaning. Frankfurt am Main: Peter Lang.

Lakoff, G. 1987. Women, fire, and dangerous things: What categories reveal about the mind. The University of Chicago Press. [Pol. Tabakowska, E. (ed.). 2011. Kobiety, ogień i rzeczy niebezpieczne. Co kategorie mówiq nam o umyśle. Kraków: Universitas.].

Lakoff, G. and M. Johnson. 1980. Metaphors we live by. University of Chicago Press. [Pol. Lakoff, G. and M. Johnson. 1988. Metafory w naszym życiu (transl. from Eng. by T.P. Krzeszowski). Warszawa: PIW.].

Langacker, R.W. 1987. Foundation of cognitive grammar. Vol. 1 Theoretical prerequisites. Stanford: Stanford University Press.

Langacker, R.W. 1990. Concept, image, and symbol. The cognitive basis of grammar. Berlin: Mouton de Gruyter.

Langacker, R.W. 2000. "A dynamic usage-based model”. In: Barlow, M. and S. Kemmer (eds.). Usagebased models of language. Stanford: CSLI Publications. 1-63. [Pol. Langacker, R.W. 2003. Model dynamiczny oparty na uzusie językowym. In: Dąbrowska, E. and W. Kubiński (eds.). Akwizycja języka w świetle językoznawstwa kognitywnego. Kraków: Universitas. 30-117].

Langacker, R.W. 2008. Cognitive grammar. A basic introduction. Oxford: Oxford University Press. [Pol. Langacker, R.W. 2009. Gramatyka kognitywna. Wprowadzenie. Kraków: Universitas.].

Langacker, R.W. 2013. Essentials of cognitive grammar. Oxford University Press.

Lauterbach, E. 2009. Sprechfehler und Interferenzprozesse beim Dolmetschen. Frankfurt am Main: Peter Lang.

Lewandowski, M. 2013. The language of football: an English-Polish contrastive study. Poznań: Wydawnictwo Naukowe UAM.

Libura, A. 2010. Teoria przestrzeni mentalnych i integracji pojęciowej. Struktura modelu i jego funkcjonalność. Wrocław: Wydawnictwo Uniwersytetu Wrocławskiego.

Lipczuk, R. 1992. „Internacjonalizmy a „fałszywi przyjaciele” tłumacza”. Język a kultura 7: Kontakty języka polskiego z innymi językami na tle kontaktów kulturowych. 135-143.

Lipczuk, R. and D. Buncic. 2003. An online bibliography on false friends. http://www.uni-bonnde/ $\sim$ dbuncic/ffbib

Maćkiewicz, J. 1992. „Wyrazy międzynarodowe a kształtowanie się europejskiej ligi słownikowej”. Język a Kultura 7: Kontakty języka polskiego z innymi językami na tle kontaktów kulturowych. $145-153$.

Marcinkiewicz, J. 2011. „Kognitywne i strukturalne podłoże interferencji morfo-syntaktycznej w języku litewskim - i nie tylko". Zeszyty Glottodydaktyczne Jagiellońskiego Centrum Językowego 3. 137-156.

Marcinkiewicz, J. 2013. „O kognitywnym rozumieniu interferencji oraz transferu językowego w akwizycji L2”. Scripta Neophilologica Posnaniensia 13. 67-75.

Marcinkiewicz, J. 2014. "The metaphor in feedback transfer in L2 acquisition (with some examples of the interaction between the Polish and Lithuanian languages)". In: Rudnicka-Szozda, K. and A. Szwedek (eds.). Cognitive linguistics in the making. Frankfurt am Main: Peter Lang. 185-196.

Marcinkiewicz, J. 2016. "Verb transfer in L2 acquisition vs stage model figure/ground: a case study with evidence from Lithuanian and German”. In: Fabiszak, M., Krawczak, K. and K. Rokoszewska (eds.). Cognitive categories and processes in grammar and discourse. Frankfurt am Main: Peter Lang. 297-311.

MacLaury, R.E. 1995. "Vantage theory". In: Taylor, J.R. and R.E. MacLaury (eds.). Language and the cognitive construal of the world. Berlin/New York: Mouton de Gruyter. 
Odlin, T. 1989. Language transfer: cross-linguistic influence in language learning. Cambridge: Cambridge University Press.

Odlin, T. 2008. "Conceptual transfer and meaning extensions". In: Robinson, P. and N.C. Ellis (eds.). Handbook of cognitive linguistics and second language acquisition. New York: Routlege. 306-340.

Piotrowska-Oberda, E. 2006. Transfer leksykalny w komunikacji menedżerskiej. Kielce: Wydawnictwo Akademii Świętokrzyskiej.

Podgórni, H. 2010. Interferenzbedingte Sprachfehler im lexikalischen und grammatischen Subsystem des Deutschen bei polnischen Germanistikstudenten. Kraków: Wydawnictwo Uniwersytetu Jagiellońskiego.

Rosch, E. 1978. "Principles of categorization". In: Rosch, E. and B.B. Lloyd (eds.) Cognition and categorization. Hillsdale: Lawrence Erlbaum. 27-48.

Stownik Języka Polskiego PWN. www.sjp.pwn.pl

Synonimy.pl - Stownik synonimów języka polskiego. www.synonimy.pl

Szpila, G. 2003. A dictionary of English-Polish false friends. Kraków: Egis.

Taylor, J.R. 1989. Linguistic categorization. Prototypes in linguistic theory. London: Oxford University Press. [Pol. Taylor, J.R. 2001. Kategoryzacja w języku. Prototypy w teorii językoznawczej. Kraków: Universitas.].

Wilczyńska, W. 1992. „Faux amis” czy „amis infideles” - definicja i praktyka”. Język a kultura 7. Kontakty języka polskiego z innymi językami na tle kontaktów kulturowych. 161-168.

Wojciszke, B. and D. Doliński. 2010. „Psychologia społeczna”. In: Strelau, J. and D. Doliński (eds.). Psychologia akademicka. Podręcznik. Vol. 2. Gdańsk: Gdańskie Wydawnictwo Psychologiczne. 293-447. 